\begin{tabular}{cc|c}
\hline Tar. Bil. Der. & $\begin{array}{c}\text { Tarım Bilimleri Dergisi } \\
\text { Dergi web sayfası: }\end{array}$ & Journal of Agricultural Sciences \\
& www.agri.ankara.edu.tr/dergi & Journal homepage: \\
& www.agri.ankara.edu.tr/journal
\end{tabular}

\title{
A Comparative Study on Age Determination of Carp (Cyprinus carpio Linnaeus, 1758) in Lake Eğirdir Using Otolith, Vertebrae and Scale Counts
}

Yıldız BOLAT ${ }^{\mathrm{a}}$, Abdulkadir YAĞCI ${ }^{\mathrm{b}}$

${ }^{a}$ Suleyman Demirel University, Faculty of Fisheries, Department of Fisheries and Seafood Processing Technology, Isparta, TURKEY

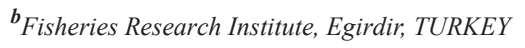

\section{ARTICLE INFO}

Research Article DOI: 10.15832/ankutbd.446437

Corresponding Author: Y1ldiz BOLAT, E-mail: yildizbolat@sdu.edu.tr, Tel: +90 (543) 7290342

Received: 12 November 2015, Received in Revised Form: 01 March 2017, Accepted: 01 March 2017

\begin{abstract}
This study, a comparative age determination study was carried out between May and November of 2013 in order to estimate most reliable bony tissue for ageing of the common carp in Lake Eğirdir. A total of 78 specimens aged between 1 and 11 were used in the study, having weights between 191 and $8685 \mathrm{~g}$ and fork lengths between 19.5 and $76 \mathrm{~cm}$. Scales, vertebrae and otoliths were used by one reader via 5 replicates for ageing. Highest agreement among the bony tissues was found in otoliths $(10.67 \%)$ and most reliable bony tissue was determined as otoliths for age determination in Lake Eğirdir carps.
\end{abstract}

Keywords: Cyprinus carpio; Age; Otolith; Vertebrae; Scale; Eğirdir Lake

\section{Eğirdir Gölü Sazan (Cyprinus carpio Linnaeus, 1758) Balıklarında Otolit, Omur ve Pullardan Karşılaştırmalı Yaş Tayini Üzerine Bir Araştırma}

\section{ESER BILGISİ}

Araştırma Makalesi

Sorumlu Yazar: Y1ldız BOLAT, E-posta: yildizbolat@sdu.edu.tr, Tel: +90 (543) 7290342

Geliş Tarihi: 12 Kasım 2015, Düzeltmelerin Gelişi: 01 Mart 2017, Kabul: 01 Mart 2017

\section{ÖZET}

Bu çalışma, Eğirdir Gölü sazan balıklarının yaş tayininde en güvenilir kemiksi dokunun belirlenmesi amacıyla karşılaştırmalı bir yaş tayin çalışması olarak Mayıs-Kasım 2013 tarihleri arasında gerçekleştirilmiştir. Çalışmada toplam 78 adet yaşları 1 ile 11, ağırlıkları $191 \mathrm{~g}$ ile $8685 \mathrm{~g}$ ve çatal boyları $19.5 \mathrm{~cm}$ ile $76 \mathrm{~cm}$ arasında değişen bireyler kullanılmıştır. Yaş tayini tespitinde pullar, omur ve otolitler kullanılmış ve 5 tekrarlı okuma yapılmıştır. Kemiksi yapılar arasında en yüksek uyum (\% 10.67), otolit olarak belirlenmiş ve Eğirdir Gölü sazan balıklarında yaş tayini için en güvenilir kemiksi yapının otolit olduğu tespit edilmiştir.

Anahtar Kelimeler: Cyprinus carpio; Yaş; Otolit; Omur; Pul; Eğirdir Gölü

(C) Ankara Üniversitesi Ziraat Fakültesi 


\section{Introduction}

Various bony structures including scales, otolith, vertebrae, fin rays and spines, opercular bones, cleithra have been utilized to estimate the age of different fish species (Das 1994; Worthington et al 1995; Göçer \& Ekingen 2005; Khan et al 2011; Başusta et al 2014). There are numerous studies on usage of this practice for age determination of the common carp also (Lubinski et al 1984; Yerli 1997; Brown et al 2004; Balık et al 2006; Demirkalp 2007; Phelps et al 2007; Yılmaz \& Polat 2008; Apaydın Yağcı et al 2008a; 2008b; Amouei et al 2013; Mert \& Bulut 2014).

Ambrose (1989) stated that age determination is the most critical issue in fisheries biology studies and Chalanchuk (1984) reported age estimation with high precision is among the things to obtain accurate data on population dynamics during fish biology studies (Türkmen et al 2005). However, it is reported that peculiar features of each species like the timing of annulus formation, latent period of growth, breeding and migration activities should be known prior to age determination, and since the ideal bony structure or age determination method may vary among species, even age classes and populations of the same species, it is advised to perform confirmation studies on age determination which can be affected by a number of variables for the sake of the reliability of the method applied (Polat 2000).

Being an indispensable data source in fisheries management, reliable and precise age determination is of utmost importance in monitoring fish populations. The present study focuses on age determination by using three different bony structures of common carp in Eğirdir Lake.

\section{Material and Methods}

\subsection{Sampling of the fish}

The study material consisted of 78 Cyprinus carpio specimens collected with trammel nets having the mesh sizes 55, 60, 65, 70 and $80 \mathrm{~mm}$ from different parts of Eğirdir Lake between May and November 2013. Fork lengths (FL, mm) and weights ( $\mathrm{g}$ ) were recorded for each specimen caught.

\subsection{Scales preparation}

After measurements, scales were removed from above left lateral line under dorsal fin from near head region (Chugunova 1963). Scales from each fish were kept in petri dishes with warm water for 10-12 hours. Following the cleansing of mucus and the pigment layer via a brush, the scales were placed into $5 \% \mathrm{NaOH}$ for 2 hours, then washed with distilled water and put into $96 \%$ ethanol for minutes to get rid of the water. Afterwards, the scales preserving structural unity and intact nucleus under light were placed between two slides and preparations were made. The study was performed via a Nikon Profile Projector V-10 imaging device and under a constant magnification rate (10x) (Figure 1).
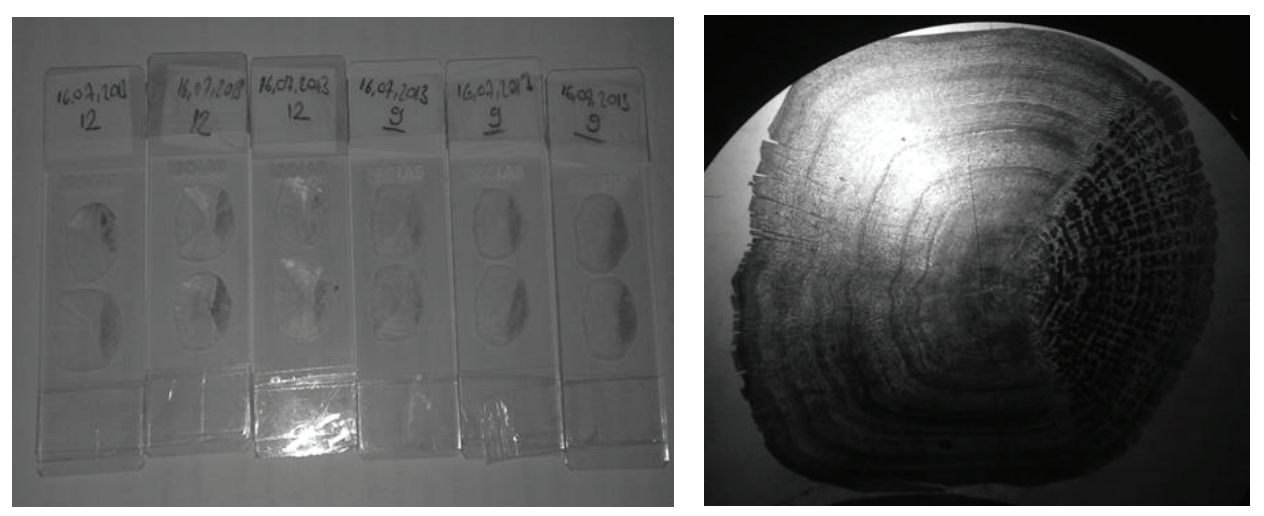

Figure 1- Scale preparations and annulus 


\subsection{Vertebra preparation}

All vertebrae between the fifth to tenth were taken out after removal of the internal organs and cleansing (Chugunova 1963), kept in boiling water for 3 minutes, cleaned from tissue remains and air dried. The polyester molds prepared with $100 \mathrm{~g}$ polyester (styrene (100-42-5)) and $2 \mathrm{~g}$ hardener (methyl ethyl ketone peroxide) under $70^{\circ} \mathrm{C}$ in a preheated incubator for two hours (Figure 2), instead of the suggested method using $100 \mathrm{~g}$ polyester with 20-40 drops of catalyst under $35^{\circ} \mathrm{C}$ incubator treatment (Metin 2001).

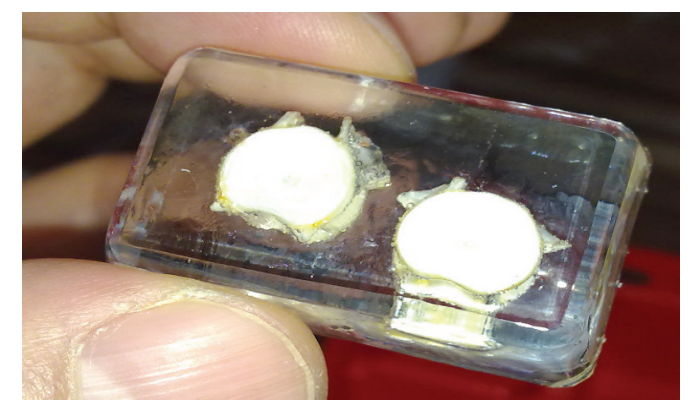

Figure 2- A mould filled with common carp vertebrae fixed in clear polyester resin

A Micracut 201 prevision cutter was used for sectioning. Prior to sectioning, centre of each vertebra was marked. $0.5 \mathrm{~mm}$ sections were cut via two blades with $40-50 \mu \mathrm{m} \mathrm{sec}^{-1}$ feed rate and 400$500 \mathrm{rpm}$ speed (Figure 3).

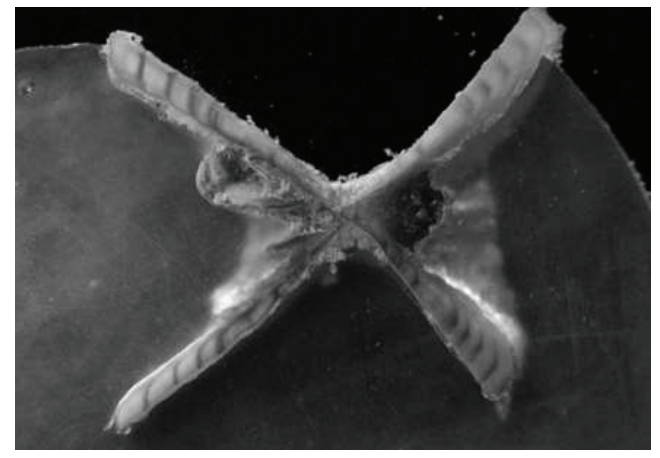

Figure 3- Translucent and opaque bands in vertebral section
Scratches were removed with $200 \mu$ sandpaper. Readings were made under binocular microscope illuminated from the top and sides with the same magnification rate (10x). The images were captured imaging system and ageing was made through images.

\subsection{Otolith preparation}

Head portions of the fish were cut from midline and the otoliths were removed from otolith capsules with pincers (Chugunova 1963), the otoliths were cleaned in $96 \%$ ethanol and placed into Eppendorf tubes with glycerin. After three weeks, otoliths were studied under binocular microscope illuminated from the top and sides with the same magnification rate (10x). The images were captured imaging system and ageing was made through images (Figure 4).

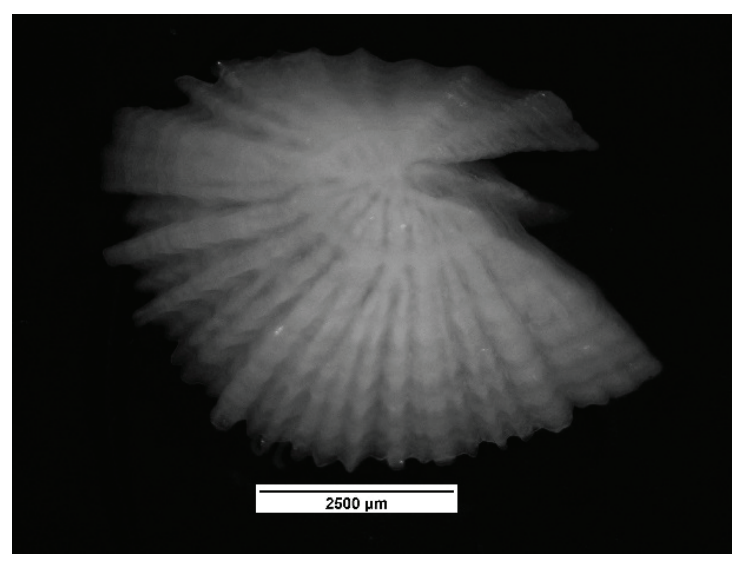

Figure 4- Translucent and opaque bands in carp otolith

Readings were made by a single reader and 5 replicates at different times. Last complete annulus were taken into account for ageing, determination of last annual ring based on $1^{\text {st }}$ January accepted as the birthday for fishes of northern hemisphere.

\subsection{Calculation of mean age}

According to Baker and Timmons (1991), calculation of mean age aims to determine over-or underestimations. To calculate mean age Equation 1 was used (Bostanc1 2005). 


$$
X_{k t}=\frac{\sum_{i}^{n} \sum_{j}^{f} x_{i j k t}}{n . f}
$$

Where; $x_{i j k t}, \mathrm{j}$ fish; $\mathrm{i}$, readings; 1 , age value of reading; $n$, replicate; $f$, total number of specimens. Although not without certainty about reliability of a certain structure over other, mean age gives a preliminary idea about presence of a reading over or below normal values (Bostanc1 2005).

\subsection{Agreement of otolith, vertebrae and scales}

This value helps to determine the criteria to evaluate annuli. If all 3 readings give the same age in a study with 3 replicates, the similarity will be zero or in other words agreement is $100 \%$. Higher agreement is preferred, although this doesn't prove the reliability of a certain structure. In short agreement is an important index for age analyses, although solely not enough the ensure reliability (Bostanc1 2005). Rate of agreement over 5 readings can be expressed as $5 / 5,4 / 5,3 / 5,2 / 5,1 / 5$, and demonstrated as a percentage $(\%)$ of the specimen number in the expression to all specimens. The structure with highest agreement is accepted as the most reliable (Y1lmaz 2000). Five replicates were applied in our study.

\subsection{Variance analysis of otolith, vertebrae and scales}

Age estimation data obtained from 5 different readings for each structure was subjected to variance analysis (Equation 2). Fowler (1990) describes variance as the sum of squares mean age estimates minus mean age over degrees freedom (Y1lmaz 2000).

$V_{t}=\frac{\sum_{i}^{n}\left(X_{i}-\bar{X}\right)}{n-1}$
Where; $V$, the variance for the structure $\mathrm{t} ; n$, number of replicates; $X$, first reading for each sample; $\bar{X}$, mean of replicates.

\subsection{Ageing error}

For each age estimation of a certain bony structure after 5 replicates, error rate was calculated after variance analysis. Ageing error $\left(\mathrm{S}_{\mathrm{t}}\right.$, standard deviation) is expressed as the square root of the variance (Equation 3) (Yilmaz 2000). Lowest standard error gives the most reliable structure (Yilmaz 2000).

$S_{t=\sqrt{V_{t}}}$

\subsection{Data analysis}

Minimum age, maximum age, mean age, standard deviation, standard error, variance and $\mathrm{CV}$ values were analyzed using JMP 8 package program.

\section{Results and Discussion}

Distribution of weights in the 78 carps caught from Lake Eğirdir ranges between 191 and 8685 g, while the fork lengths range between $19.5 \mathrm{~cm}$ and $76 \mathrm{~cm}$.

\subsection{Age composition of otolith, vertebrae and scales}

According to 5 reading replicates, age composition estimated for each bony structure is different. Scale readings of 78 carps give age distribution as 1-11, of 63 specimens (as in 15 samples no annulus formation was detected) vertebrae readings give it as 2-11 and according to readings from 75 specimens (as 3 otoliths were broken upon removal) it is found as $2-10$ (Table 1$)$.

Table 1- Age composition derived from different bony structures readings

\begin{tabular}{lrrrrrrrrrrrr}
\hline \multirow{2}{*}{ Bony structure } & \multicolumn{10}{c|c}{ Age } & \multicolumn{10}{c}{ Total } \\
\cline { 2 - 11 } & $I$ & $I I$ & $I I I$ & $I V$ & $V$ & $V I$ & VII & VIII & $I X$ & $X$ & $X I$ & \\
\hline Scales & 1 & 10 & 6 & 7 & 10 & 12 & 11 & 12 & 4 & 3 & 2 & 78 \\
Vertebrae & - & 7 & 9 & 2 & 4 & 11 & 13 & 11 & 3 & 2 & 1 & 63 \\
Otolith & - & 7 & 9 & 12 & 7 & 8 & 14 & 12 & 5 & 1 & - & 75 \\
\hline
\end{tabular}


When the average estimates were compared for each bony structure, were found to be around 5 , no statistical difference was observed $(\mathrm{P}>0.05)$. Standard errors and reading errors for bony structure-reader combinations are given in Table 2. Accordingly, lowest standard error and ageing errors are calculated in otoliths.

Table 2- Mean ages, standart and ageing errors in different bony structures for common carp

\begin{tabular}{lccc}
\hline Bony structures & Scales & Vertebrae & Otoliths \\
\hline Mean ages & 5.76 & 5.88 & 5.64 \\
Standard errors & 0.28 & 0.30 & 0.25 \\
Ageing errors & 2.44 & 2.38 & 2.21 \\
\hline
\end{tabular}

When the agreement among otoliths, vertebrae and scales of carps in Lake Eğirdir were investigated to find the most reliable bony structure, according to 5 different readings at different times, the evaluations of the percentages of shared readings for all five replicates over all readings are given in Table 3.

Table 3- Precision of readers on different bony structures (\%)

\begin{tabular}{|c|c|c|c|c|c|c|}
\hline \multirow{2}{*}{$\begin{array}{l}\text { Bony } \\
\text { structure }\end{array}$} & \multicolumn{5}{|c|}{$\begin{array}{c}\text { Aagreement of readers/number of } \\
\text { total readings }\end{array}$} & \multirow[t]{2}{*}{ Total } \\
\hline & $5 / 5$ & $4 / 5$ & $3 / 5$ & $2 / 5$ & $1 / 5$ & \\
\hline Scales & 7.69 & 29.49 & 38.46 & 24.36 & - & 100 \\
\hline Vertebrae & 7.94 & 25.40 & 34.92 & 31.74 & - & 100 \\
\hline Otolith & 10.67 & 28.00 & 36.00 & 25.33 & - & 100 \\
\hline
\end{tabular}

This study is the first to be based on comparison of methodologically different bony structures in Lake Eğirdir fishes. As in similar studies, the most reliable age estimation is based on the lowest reading error and otolith readings had the lowest error (2.21) (Table 2). According to 5 different readings of the same reader, the highest agreement was found otolith (10.67) and the lowest in scales (7.69) (Table 3). Polat et al (2001) in Black Sea flounders and Polat et al (2004) in Derbent Dam perch found the highest reader agreement and the lowest reading error in vertebrae. Likewise, in a study on comparison of 6 different structures in carps of Altınkaya, Derbent Dams and Balık Lake (Bafra), Yılmaz \& Polat
(2008) have found the highest reader agreement and the lowest reading error in vertebrae for each lake. On the other hand, Temizer \& Şen (2008) found among Keban Dam mirror carps the highest reader agreement between scales and vertebrae (86.68\%).

There are many studies on use of scales to obtain the most suitable bony structure and process for age determination (Yerli 1997; Campana 2001; Balık et al 2006; Apaydın Yağc1 et al 2008a, b). However, otoliths were found as the most reliable ageing structure in Carassius gibelio from Lake Eğirdir (Bostanc1 2005), whereas vertebrae were more precise as compared to otoliths in Alosa pontica (Yilmaz 2000) and in Carassius gibelio in Lake Bafra (Bostanc1 2005).

\section{Conclusions}

In conclusion, according to the highest agreement and lowest ageing error values, otolith is the ideal bony structure for precise age determination in Lake Eğirdir carps.

\section{Acknowledgements}

This study was supported by the Scientific Research Fund of Suleyman Demirel University (SDUBAP) with project number 3617-YL1-13. Furthermore, We would like to thank the Eğirdir Fisheries Research Institute.

\section{References}

Amouei F, Valinassab T \& Hailov A (2013). Age determination and morphological study using otoliths in Cyprinus carpio Linnaeus, 1758 in the Southern Caspian Sea. Iranian Journal of Fisheries Sciences 12(4): 749-758

Apaydın Yağcı M, Alp A, Yeğen V, Uysal R, Yağcı A \& Ceylan M (2008a). The growth characteristics of carp (Cyprinus carpio L., 1758) population in Lake Iş1klı (Çivril-Denizli). Ege University Journal of Fisheries \& Aquatic Sciences 25(4): 337-341

Apaydın Yağcı M, Uysal R, Yeğen V, Çetinkaya S, Cesur M, Bostan H \& Yağcı A (2008b). The some biological features of carp population (Cyprinus carpio L., 1758) in Lake İznik (Bursa). Ege University Journal of Fisheries \& Aquatic Sciences 25(1): 19-25 
Balık İ, Çubuk H, Özkök R \& Uysal R (2006). Some characteristics and size of carp (Cyprinus carpio L., 1758) population in the Lake Karamik (Afyonkarahisar/Turkey). Turkish Journal of Fisheries and Aquatic Sciences 6: 117-122

Başusta A, Başusta N, Aydin R, Ozer E I \& Girgin H (2014). Age determination of red-spotted trout (Salmo macrostigma) inhabiting Munzur Stream, Turkey. Pakistan Journal of Zoology 46(5): 1351-1356

Bostanc1 D (2005). Bafra Balık Gölü ve Eğirdir Gölü'nde yaşayan balık populasyonlarında opak birikim analizi ile yaş doğrulaması. Doktora tezi, Ondokuz Mayıs Üniversitesi Fen Bilimleri Enstitüsü (Basılmamış), Samsun

Brown P, Green C, Sivakumaran K P, Stoessel D \& Giles A (2004). Validating otolith annuli for annual age determination of common carp. Transactions of the American Fisheries Society 133: 190-196

Campana S E (2001). Accuracy, precision and quality control in age determination, including a review of the use and a buse of age validation methods. Journal of Fish Biology 59: 197-242

Chugunova N I (1963). Age and Growth Studies in Fish, Israel Program Scientific Translation. No: 610, National Science Foundation, Washington. 132

Das M (1994). Age determination and longevity in fishes. Gerontology 40: 70-96

Demirkalp F Y (2007). Some of the growth characteristics of carp (Cyprinus carpio L., 1758) in Çernek Lake (Samsun, Turkey). Hacettepe University Journal of Biology and Chemistry 35(1): 57-65

Fowler J A (1990). Validation of Annual Growth Increments in the Otoliths of a Small, Tropical Coral Reef Fish, Marine Ecology Progress Series 64: 25-38

Göçer M \& Ekingen G (2005). Comparisons of various bony structures for the age determination of liza ramada (Risso, 1826) population from the Mersin Bay. Ege University Journal of Fisheries \& Aquatic Sciences 22(1-2): 211-213

Khan S, Khan M A \& Miyan K (2011). Comparison of age estimates from otoliths, vertebrae, and pectoral spines in African sharptooth catfish, Clarias gariepinus (Burchell). Estonian Journal of Ecology 60(3): 183-193

Lubinski K S, Jackson S D \& Hartsfield B N (1984). Age structure and analysis of carp populations in the Missisippi Illinois Rivers. Illinois Natural History Survey, Aquatic Biology Technical Report, pp. 28
Mert R \& Bulut S (2014). Some biological properties of carp (Cyprinus carpio L., 1758) introduced into Damsa Dam Lake, Cappadocia Region, Turkey. Pakistan Journal of Zoology 46(2): 337-346

Metin G (2001). Otolitten yaş tayininde kesit alma tekniği. Ege Üniversitesi Su Ürünleri Dergisi 18(12): 271-277

Phelps Q E, Edwards K R \& Willis D W (2007). Precision of five structures for estimating age of common carp. North American Journal of Fisheries Management 27: 103-105

Polat N (2000). Balıklarda yaş belirlemenin önemi. IV. Su Ürünleri Sempozyumu, 28-30 Haziran, Erzurum, s. $9-20$

Polat N, Bostanc1 D \& Y1lmaz S (2001). Comparable age determination in different bony structures of Pleuronectes flesus luscus inhabiting the Black Sea. Turkish Journal of Zoology 25: 441-446

Polat N, Bostanc1 D \& Y1lmaz S (2004). Age analysis on different bony structures of perch (Perca fluviatilis L. 1758) inhabiting Derbent Dam Lake (Bafra-Samsun). Turkish Journal of Veterinary and Animal Sciences 28: 465-469

Temizer İ A \& Şen D (2008). Keban Baraj Gölü'nde yaşayan aynalı sazan (Cyprinus carpio L.,1758)'da kemiksi yapılardan karşılaştırmalı yaş tayini. Fırat Üniversitesi Fen ve Mühendislik Bilimleri Dergisi 20(1): 57-66

Türkmen M, Başusta N \& Demirhan S A (2005). Balıklarda Yaş Tayini. In: M Karataş (Ed), Balık Biyolojisi Araştırma Yöntemleri. Nobel Yayın Dağıtım, Ankara, $498 \mathrm{~s}$

Worthington D G, Fowler A J \& Doherty P J (1995). Determining the most efficient method of age determination for estimating the age structure of a fish population. Canadian Journal of Fisheries Aquatic Science 52: 2320-2326

Yerli S V (1997). An investigation on the growth criterias of Cyprinus carpio Linnaeus 1758 in Ç1ldır LakeArdahan. Turkish Journal of Zoology 21: 91-99

Yılmaz S (2000). Karadeniz'de yaşayan tirsi balığı (Alosa pontica Eichw., 1838)'nda yaş belirleme metotları. Yüksek lisans tezi, Ondokuz Mayıs Üniversitesi Fen Bilimleri Enstitüsü (Basılmamış), Samsun

Yilmaz S \& Polat N (2008). Cyprunus carpio L., 1758 (sazan)'nun yaş tayini için farklı kemiksi yapıların değerlendirilmesi. Süleyman Demirel Üniversitesi Fen Edebiyat Fakültesi Fen Dergisi 3(2): 149-161 